\title{
Parasite load and risk factors for poor outcome among children with visceral leishmaniasis. A cohort study in Belo Horizonte, Brazil, 2010-2011
}

\author{
Maria Vitória Assumpção Mourão', Antonio Toledo Jr², \\ Luciana Inácia Gomes ${ }^{3}$, Verônica Vieira Freire ${ }^{3}$, Ana Rabello ${ }^{3 /+}$ \\ ${ }^{1}$ Hospital Infantil João Paulo II, Fundação Hospitalar do Estado de Minas Gerais, Belo Horizonte, MG, Brasil \\ ${ }^{2}$ Serviço Multiprofissional de Infectologia, Universidade José do Rosário Vellano-UNIFENAS, Belo Horizonte, MG, Brasil \\ ${ }^{3}$ Laboratório de Pesquisas Clínicas, Centro de Pesquisas René Rachou-Fiocruz, Belo Horizonte, MG, Brasil
}

Clinical and laboratory risk factors for death from visceral leishmaniasis (VL) are relatively known, but quantitative real-time polymerase chain reaction (qPCR) might assess the role of parasite load in determining clinical outcome. The aim of this study was to identify risk factors, including parasite load in peripheral blood, for VL poor outcome among children. This prospective cohort study evaluated children aged $\leq 12$ years old with VL diagnosis at three times: pre-treatment (T0), during treatment (T1) and post-treatment (T2). Forty-eight patients were included and $16(33.3 \%)$ met the criteria for poor outcome. Age $\leq 12$ months [relative risk (RR) 3.51; 95\% confidence interval (CI) 1.89-6.52], tachydyspnoea (RR 3.46; 95\% CI 2.19-5.47), bacterial infection (RR 3.08; 95\% CI 1.27-7.48), liver enlargement (RR 3.00; 95\% CI 1.44-6.23) and low serum albumin (RR 7.00; 95\% CI 1.80-27.24) were identified as risk factors. $q P C R$ was positive in all patients at T0 and the parasite DNA was undetectable in $76.1 \%$ of them at T1 and in $90.7 \%$ at T2. There was no statistical association between parasite load at T0 and poor outcome.

Key words: visceral leishmaniasis - parasite load - risk factors - children - Brazil

It is estimated that there are between 200,000 400,000 cases of visceral leishmaniasis (VL) in the world annually. Over $90 \%$ of these occur in six countries: India, Bangladesh, Sudan, South Sudan, Ethiopia and Brazil (Alvar et al. 2012). In Brazil, there has been an increase in the number of the VL cases over the past few decades, with an annual average of 3,484 cases between 2000-2010 (MS 2011a, b). Over the last decade, a high lethality rate has been observed, ranging from 3.2$8.5 \%$ (MS 2011a, b).

Belo Horizonte, the capital of the state of Minas Gerais, an endemic region for VL, also showed an increase in VL cases, with an annual average of 83 cases per year between 2000-2004 and 132 cases per year between 2005-2010. The lethality rate in Belo Horizonte between 2006-2011 was higher than the national average, ranging from 8.1-23\% ( PBH/SMS 2012).

Previously identified risk factors for death are prolonged course of the disease, very old and very young age, malnutrition, vomiting, diarrhoea, jaundice, bleeding, dyspnoea, oedema, coinfection with human immu-

doi: 10.1590/0074-0276140257

Financial support: FAPEMIG (APQ-02819-10)

FAPEMIG provided scientific initiation scholarship for the undergraduate student VVF, AR is a research fellow of $\mathrm{CNPq}$ [304881/2009-0]

+ Corresponding author: ana@cpqrr.fiocruz.br

Received 10 May 2013

Accepted 5 December 2013 nodeficiency virus, bacterial coinfection, severe anaemia, leucocytosis, neutrophilia and neutropaenia (Seaman et al. 1996, Lyons et al. 2003, Werneck et al. 2003, Collin et al. 2004, Rey et al. 2005, Mueller et al. 2009, Costa et al. 2010, Sampaio et al. 2010).

Various infectious diseases, such as acquired immune deficiency syndrome and hepatitis $\mathrm{C}$, have a clear correlation between microorganism load and disease outcome (Ghany et al. 2011, Panel on Antiretroviral Guidelines for Adults and Adolescents 2013). Two studies assessed the association between pre-treatment parasite counts and VL outcome. These studies, from Sudan and Brazil, showed that higher number of parasites in the spleen or bone marrow $(\mathrm{BM})$ were associated with a higher death rate (Seaman et al. 1996, Costa et al. 2010). Both studies used microscopic methods for parasite quantification, which have limitations due to the invasive procedures required to obtain the spleen and BM aspirates and the excessive time required for the analysis of these samples (da Silva et al. 2005). Quantitative real-time polymerase chain reaction (qPCR) is a technique that can quantify parasite load in an accurate manner in different biological samples, including peripheral blood. Moreover, it provides results more rapidly than microscopic techniques, with less DNA contamination and fewer false positive results than standard PCR (Kubista et al. 2006).

Considering VL severity and lethality rate, the early identification of factors associated with poor outcome and death is relevant to the premature establishment of appropriate treatment. The objective of this study was to identify risk factors, including parasite load quantified by qPCR in the peripheral blood, for VL poor outcome among children. 


\section{SUBJECTS, MATERIALS AND METHODS}

Patients and clinical assessment - This was a prospective cohort study conducted at João Paulo II Hospital (HJPII) of Hospital Foundation of Minas Gerais State (FHEMIG) from June 2010-June 2011.

The inclusion criteria were hospitalisation at HJPII, age $\leq 12$ years old and laboratory-confirmed VL by one of the following methods: BM smear, PCR (k-DNA) in $\mathrm{BM}$ aspirate or in peripheral blood, indirect immunofluorescence antibody test or rk39 immunochromatographic antigen test (Kala-azar Detect ${ }^{\mathrm{TM}}$ or Diamed IT-Leish ${ }^{\mathrm{TM}}$ ). All patients with confirmed VL in the study period were invited to participate the study.

The main endpoint was poor outcome, characterised by at least one of the following interventions: admission to the intensive care unit (ICU), administration of vasoactive amines, mechanical ventilation or transfusion of blood products (red blood cells, platelets or fresh frozen plasma). Demographic and clinical characteristics and laboratory findings were assessed before the initiation of treatment.

The patients underwent three clinical evaluations: pre-treatment (T0), between 10-15 days of treatment (T1) and between 40-60 days after initiation of treatment (T2). Spleen and liver sizes were measured, considering their extensions below the costal margin at midclavicular line. Then, the measures were divided by child body surface, in order to obtain an adjusted measure, comparable between all children, despite the weight and height variation observed among these patients. In each clinical evaluation, peripheral blood samples were withdrawn for parasite load assessment. For the continuous measures, such as laboratory values, cut points were defined according to Brazilian and international guidelines.

Parasite load by qPCR quantification - Total DNA from peripheral blood samples was extracted using the QIAamp DNA Mini Kit (Qiagen GmbH, Hilden, Germany), according to the manufacturer's instructions. Two independent assays for the detection and quantification of Leishmania spp and human DNA were performed using the StepOnePlus ${ }^{\mathrm{TM}}$ Real-Time PCR System (Life Technologies, Carlsbad, CA, USA). For the Leishmania assay, the target DNA was the small-subunit ribosomal RNA (SSU rRNA) gene, which is conserved among all Leishmania species. The Leishmania assay consisted of the primers LEIS.U1 (5'-AAGTGCTTTCCCATCGCAACT-3') and LEIS.L1 (5'-GACGCACTAAACCCCCTCCAA-3'), designed to amplify a 67-bp fragment and the fluorogenic probe LEIS.P1 (FAM 5'-CGGTTCGGTGTGTGGCGCC3'TAMRA). The protocol described by Gomes et al. (2012) was applied. For the human assay, the $A C T B$ reference gene was used as the target and the primers Acol and Aco2 (Musso et al. 1996), which generate 120-bp fragments, were used in this assay. The reaction mixtures contained $12.5 \mu \mathrm{L}$ of Syber $^{\circledR}$ Green PCR Master Mix 2X (Life Technologies), $0.1 \mu \mathrm{M}$ of each primer and $3 \mu \mathrm{L}$ of DNA template in a final volume of $25 \mu \mathrm{L}$. The cycling parameters were universal and the melting analysis was conducted based on the parameters of the StepOnePlus ${ }^{\mathrm{TM}}$ Real-Time PCR System.
Standard curves were prepared for each assay using known quantities of $\mathrm{pCR}^{\mathrm{TM}} 4 \mathrm{TOPO}^{\mathrm{TM}}$ vector (Life Technologies) containing the cloned human gene (ACTB, 120 bp) and the $67 \mathrm{bp}$ Leishmania infantum SSU rRNA fragment. The recombinant plasmids were serially diluted 1:10 to create each standard curve. The quality parameters of the standard curves, including PCR efficiency, linear dynamic range and correlation coefficient, were obtained by software analysis and were accurate and similar to those obtained in previous studies (Gomes et al. 2012, Marques et al. 2012). The parasite load was expressed by the Leishmania DNA load (relative copy number of the $67 \mathrm{bp}$ SSU rRNA fragment) normalised against the reference gene $A C T B$, according to Overbergh et al. (1999). ACTB copy numbers for the target samples were divided by the highest $A C T B$ value obtained by the experiment, resulting in a correction factor used for normalisation.

Statistical analysis - The Statistical Package for Social Sciences $\left(\mathrm{SPSS}^{\circledR}\right.$ ) 14.0 (IBM Corporation, New York, NY, USA) was used for data management and statistical analysis. Categorical variables were analysed by the chisquare test and, when appropriate, the Fisher exact test was used. For continuous variables, the Student $t$ test and Wilcoxon test were utilised. The relative risk (RR) and the $95 \%$ confidence interval (CI) were calculated as a measure of effect of the dichotomous and categorical variables on the outcome. The variables with missing values above $50 \%$ were excluded from the analysis. A significance level of 5\% was used.

Ethics - This work was conducted in accordance with the Declaration of Helsinki and with Brazilian rules on human research. The study was approved by the Ethical Committees of the Research Centre René Rachou/ Oswaldo Cruz Foundation and of FHEMIG. All parents or guardians signed an informed consent form prior to the study.

\section{RESULTS}

Forty-eight patients were included in the study. The average age was 3.3 years, ranging from three-nine years old. Thirty-seven children (77.1\%) were under five years old and $25(52.1 \%)$ were male. The median time between the onset of symptoms and hospital admission was 26 days, ranging from four-180 days.

In $\mathrm{T} 0$ evaluation, the most frequent symptoms were as follows: fever (48 patients, $100 \%)$, pallor $(42,87.5 \%)$, malaise (39, 81.2\%), abdominal distension $(39,81.2 \%)$, hyporexia $(32,66.7 \%)$, weight loss $(27,56.2 \%)$, vomiting $(26,54.2 \%)$ and abdominal pain $(23,47.9 \%)$. The most frequently observed signs on physical examination were the following: pallor $(48,100 \%)$, splenomegaly (47, $97.9 \%)$ and hepatomegaly $(46,95.8 \%)$.

The initial treatment was meglumine antimoniate in 26 children (54.2\%), amphotericin B deoxycholate in 15 (31.2\%), liposomal amphotericin B in two (4.2\%) and a combination of a single dose of liposomal amphotericin followed by meglumine antimoniate in five (10.4\%). In six patients $(12.5 \%)$, the initial treatment was changed. In 37 patients, drug choice was based on assistant physi- 
cian decision, according to Brazilian Ministry of Health recommendations. In other 11 patients, the initial drug was chosen based on a concomitant clinical trial that was taking place at the same hospital. Four patients who initially received meglumine antimoniate finished the treatment with amphotericin B deoxycholate, due to an initial inadequate treatment response. In two other patients, amphotericin B deoxycholate was replaced by liposomal amphotericin B, due to acute renal lesion. The mean treatment duration was 22 days.
During hospitalisation, 16 patients $(33.3 \%)$ met the criteria for poor outcome: 11 underwent blood transfusion, three underwent blood transfusion and were admitted to the ICU, one was admitted to the ICU and required mechanical ventilation and one underwent blood transfusion, was admitted to the ICU and required mechanical ventilation and vasoactive amine treatment. There was no death related to VL in the study period.

The risk factors for poor outcome identified at $\mathrm{T} 0$ were the following (Table): age $\leq 12$ months (RR 3.51; 95\% CI

TABLE

Association between demographic, clinical and laboratory findings and poor outcome in children with visceral leishmaniasis hospitalised at João Paulo II Hospital, June 2010-June 2011

\begin{tabular}{|c|c|c|c|c|c|c|}
\hline \multirow[b]{2}{*}{ Variables } & \multirow[b]{2}{*}{$\mathrm{n}$} & & \multicolumn{2}{|c|}{$\begin{array}{l}\text { Poor outcome } \\
\text { (n) }\end{array}$} & \multirow[b]{2}{*}{$\mathrm{p}$} & \multirow{2}{*}{$\begin{array}{c}\text { Relative risk } \\
\quad(95 \% \mathrm{CI})\end{array}$} \\
\hline & & & Yes & No & & \\
\hline \multirow[t]{2}{*}{ Age $\leq 12$ months } & \multirow[t]{2}{*}{48} & Yes & 6 & 1 & \multirow[t]{2}{*}{$0.01^{a}$} & \multirow[t]{2}{*}{$3.51(1.89-6.52)$} \\
\hline & & No & 10 & 31 & & \\
\hline \multirow[t]{2}{*}{ Symptoms $\geq 60$ days } & \multirow[t]{2}{*}{48} & Yes & 2 & 3 & \multirow[t]{2}{*}{$1.00^{a}$} & \multirow[t]{2}{*}{$1.23(0.39-3.90)$} \\
\hline & & No & 14 & 29 & & \\
\hline \multirow[t]{2}{*}{ Moderate or severe malnutrition } & \multirow[t]{2}{*}{48} & Yes & 1 & 2 & \multirow[t]{2}{*}{$1.00^{a}$} & \multirow[t]{2}{*}{$1.00(0.19-5.22)$} \\
\hline & & No & 15 & 30 & & \\
\hline \multirow[t]{2}{*}{ Diarrhoea } & \multirow[t]{2}{*}{47} & Yes & 5 & 9 & \multirow{2}{*}{$0.74^{a}$} & \multirow{2}{*}{$1.18(0.49-2.82)$} \\
\hline & & No & 10 & 23 & & \\
\hline \multirow[t]{2}{*}{ Vomiting } & \multirow[t]{2}{*}{47} & Yes & 9 & 17 & \multirow[t]{2}{*}{0.66} & \multirow[t]{2}{*}{$1.21(0.51-2.86)$} \\
\hline & & No & 6 & 15 & & \\
\hline \multirow[t]{2}{*}{ Bleeding (except cutaneous) } & 48 & Yes & 1 & 6 & $0.40^{a}$ & $0.39(0.60-2.50)$ \\
\hline & & No & 15 & 26 & & \\
\hline Jaundice & 48 & Yes & 2 & 0 & $0.11^{a}$ & $3.29(2.12-5.09)$ \\
\hline & & No & 14 & 32 & & \\
\hline Oedema & 48 & Yes & 6 & 5 & $0.14^{a}$ & $2.02(0.95-4.30)$ \\
\hline & & No & 10 & 27 & & \\
\hline Tachydyspnoea & 48 & Yes & 3 & 0 & $0.03^{a}$ & $3.46(2.19-5.47)$ \\
\hline & & No & 13 & 32 & & \\
\hline Bacterial infection & 48 & Yes & 11 & 9 & 0.01 & $3.08(1.27-7.48)$ \\
\hline & & No & 5 & 23 & & \\
\hline Liver enlargement $\geq 10 \mathrm{~cm}$ & 48 & Yes & 8 & 4 & $0.01^{a}$ & $3.00(1.44-6.23)$ \\
\hline & & No & 8 & 28 & & \\
\hline Spleen enlargement $\geq 10 \mathrm{~cm}$ & 48 & Yes & 13 & 19 & 0.13 & $2.17(0.72-6.53)$ \\
\hline & & No & 3 & 13 & & \\
\hline Leukocytes $\leq 1,500$ cells $/ \mathrm{mm}^{3}$ & 48 & Yes & 1 & 2 & $1.00^{a}$ & $1.00(0.19-5.22)$ \\
\hline & & No & 15 & 30 & & \\
\hline Neutrophils $\leq 500$ cells $/ \mathrm{mm}^{3}$ & 48 & Yes & 3 & 2 & $0.32^{a}$ & $1.98(0.85-4.63)$ \\
\hline & & No & 13 & 30 & & \\
\hline Prothrombin activity $\leq 70 \%$ & 41 & Yes & 10 & 16 & 0.74 & $1.15(0.49-2.74)$ \\
\hline & & No & 5 & 10 & & \\
\hline $\mathrm{AST}$ or $\mathrm{ALT} \geq 100 \mathrm{UI} / \mathrm{L}$ & 44 & Yes & 4 & 10 & $1.00^{a}$ & $0.86(0.32-2.26)$ \\
\hline & & No & 10 & 20 & & \\
\hline Total bilirubin $\geq 1.0 \mathrm{mg} / \mathrm{dL}$ & 40 & Yes & 3 & 2 & $0.32^{a}$ & $1.91(0.80-4.54)$ \\
\hline & & No & 11 & 24 & & \\
\hline Albumin $\leq 2.5 \mathrm{~g} / \mathrm{dL}$ & 44 & Yes & 14 & 8 & $<0.0001$ & $7.00(1.80-27.24)$ \\
\hline & & No & 2 & 20 & & \\
\hline Creatinine clearance $<60$ & 43 & Yes & 1 & 1 & $1.00^{a}$ & $1.58(0.38-6.77)$ \\
\hline $\mathrm{mL} / \mathrm{min} / 1.73 \mathrm{~m}^{2}$ & & No & 13 & 28 & & \\
\hline
\end{tabular}

$a$ : Fisher's exact test; ALT: alanine aminotransferase; AST: aspartate aminotransferase; CI: confidence interval. 
1.89-6.52), tachydyspnoea (RR 3.46; 95\% CI 2.19-5.47), bacterial infection (RR 3.08; 95\% CI 1.27-7.48), liver enlargement $\geq 10 \mathrm{~cm}$ (RR 3.00; 95\% CI 1.44-6.23) and serum albumin $\leq 2.5 \mathrm{~g} / \mathrm{dL}$ (RR 7.00; 95\% CI 1.80-27.24).

The qPCR was positive in all patients at T0. At T1 and $\mathrm{T} 2$, the parasitic loads were assessed in 46 and 43 patients, respectively. Two children who were not assessed at $\mathrm{T} 1$ were assessed at $\mathrm{T} 2$. There was a wide variation in qPCR at each time point (Fig. 1). As expected, a statistically significant difference was observed between the number of SSU rRNA copies (in $\left.\log _{10}\right)$ between T0-T1 (p $<0.0001)$ and T0-T2 $(\mathrm{p}<0.0001)$, but no difference was observed between T1-T2 $(\mathrm{p}=0.12)$.

Among the 46 patients assessed at T1, 35 (76.1\%) had undetectable parasite DNA, in four (8.7\%), SSU rRNA copies decreased and in the last seven (15.2\%) the parasite load remained stable. Considering the 43 patients with a parasite load assessment at T2, 90.7\% (39/43) had an undetectable parasite DNA; 29 of them were negative at $\mathrm{T} 1$, nine were positive at $\mathrm{T} 1$ and became negative and one was not tested at T1. Two children (4.7\%) showed a decrease in the number of SSU rRNA copies (in $\log _{10}$ ) compared to the previous evaluations, but the parasite DNA did not become undetectable (1 of them was not tested at T1). Two other children (4.7\%) had an undetectable parasite DNA at $\mathrm{T} 1$ and a positive test at $\mathrm{T} 2$, with a number of copies similar to that at T0 (Fig. 2).

There was no statistical association between the number of SSU rRNA copies (in $\log _{10}$ ) and the demographic, clinical and laboratory findings at $\mathrm{T} 0$. The mean parasite load was 2.94 SSU rRNA copies (in $\left.\log _{10}\right)(95 \%$ CI 2.55 3.33 ) in the poor outcome group and $3.56 \mathrm{SSU}$ rRNA copies (in $\left.\log _{10}\right)(95 \%$ CI 3.07-4.06) in the other group. Despite a low $\mathrm{p}$ value, there was no statistical correlation between poor outcome and high parasite load at $\mathrm{T} 0(\mathrm{p}=$ 0.08) (Fig. 3).

\section{DISCUSSION}

Age less than or equal to one year was related to increased lethality and poor response to pentavalent antimony use in other Brazilian studies (Santos et al. 2002, Rey et al. 2005, Costa et al. 2010). According to Braga et

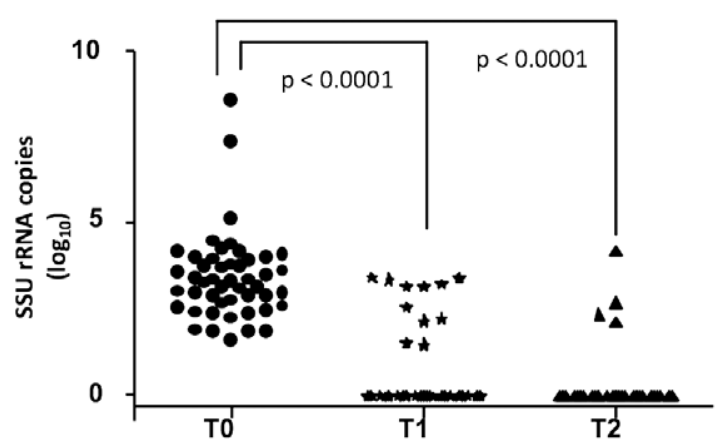

Fig. 1: number of small-subunit ribosomal RNA (SSU rRNA) copies (in $\log _{10}$ ) before starting treatment (T0), between 10-15 days after initiation of treatment (T1) and between 40-60 days after initiation of treatment (T2) in children with visceral leishmaniasis hospitalised at João Paulo II Hospital, June 2010-June 2011. al. (2013), presence of respiratory abnormalities at hospital admission was a risk factor for poor VL outcome in children. Tachydyspnoea was described as a risk factor for death by other authors (Costa et al. 2010, Sampaio et al. 2010) and its relation to disease severity can have multiple causes: interstitial pneumonitis secondary to $\mathrm{VL}$, pneumonia or thoracic restriction due to increased sizes of the liver and of the spleen. Thus, its aetiology should be investigated carefully, including the use of $\mathrm{X}$-ray images, to enable specific diagnosis and prompt treatment of the complication.

The presence of bacterial infection in patients with VL is a recognised cause of death (Rey et al. 2005, Oliveira et al. 2006, Costa et al. 2010, Sampaio et al. 2010, Araújo et al. 2012) and was associated with poor outcome in this study. In HJPII, febrile neutropaenic patients (neutrophil $<500$ cells $/ \mathrm{mm}^{3}$ ) with VL receive broad-spectrum antibiotics routinely, which could have positively influenced the disease course and may have contributed to the absence of deaths during the study period.

Increased liver size was not associated with mortality in previous studies. However, a Brazilian study suggested that the size of this organ is proportional to the duration of the illness (Pedrosa \& da Rocha 2004). Thus, larger hepatomegaly may be associated with longer duration of the disease, which has already been associated with adverse VL outcome (Seaman et al. 1996, Collin et al. 2004).

The reduction of albumin level, as observed in our study, has been associated with the severity of VL only in a study in Tunisia (Abdelmoula et al. 2003). Oedema and malnutrition, which are related to hypoalbuminaemia and are associated with higher lethality (Collin et al. 2004, Rey et al. 2005), were not identified as risk factors for poor outcome in this study. Therefore, once the change in albumin levels most likely precedes the clinical manifestations of malnutrition and oedema, monitoring of albumin levels may be relevant for early identification of potentially severe cases.

All patients with VL showed a positive pre-treatment qPCR, indicating that it may be used as a diagnostic tool, in agreement with other studies in France and Italy (Mary et al. 2006, Antinori et al. 2009). This study also showed a good association between qPCR and treatment response: $76.1 \%$ (95\% CI 60.9-87) showed an undetectable parasite DNA during treatment and $90.7 \%$ (95\% CI 78.4-96.3) had an undetectable parasite DNA at the end of the treatment, which has also been described in studies in France (Mary et al. 2004, 2006), Italy (Bossolasco et al. 2003), Tunisia (Aoun et al. 2009) and India (Sudarshan et al. 2011).

The four children who were positive by qPCR at $\mathrm{T} 2$ were considered clinically cured and did not relapse during the period of the study, which suggests that parasitaemia persistence or reemergence may not be associated with disease relapse, as described for immunosuppressed patients (Bossolasco et al. 2003, Mary et al. 2006). The positivity of qPCR at T2 could be explained by the detection of free DNA instead of viable parasites (Fisa et al. 2002) or by reinfection after return to endemic areas at $\mathrm{T} 2$. 
The finding of two patients with negative qPCR at T1 and a positive test at $\mathrm{T} 2$ reinforces this hypothesis, but it can also be explained by a fluctuation in detectable DNA.

There was no association between any of the symptoms, signs, laboratory exams and the parasite load. This finding indicates that it is not possible to predict parasite load by any parameter of easier evaluation or lower cost than qPCR.

This study was not able to show any association between parasite load and clinical outcome. This finding differs from the results of previous studies in Sudan and Northeast Brazil (Seaman et al. 1996, Costa et al. 2010), which showed that a large number of parasites in the splenic aspirate and the BM aspirate, respectively, were related to a higher risk of death. These differences could be explained by the absence of association between the parasite counts in spleen, BM and peripheral blood and also by the different techniques used (optic microscopic vs. qPCR). The difference in study endpoints, death (Sudan and Northeast Brazil) and poor outcome (current study) could also explain this difference. It is important to emphasise that no deaths were observed in this study. The wide variation in SSU rRNA copies (in $\log _{10}$ ), as reported by other authors in France (Mary et al. 2004, 2006), Italy (Bossolasco et al. 2003), Tunisia (Aoun et al. 2009) and India (Sudarshan et al. 2011) and the limited sample size may also have contributed to this finding.

Although not statistically significant, there was a tendency of association between high parasite load and good outcome. This finding is in accordance with the high influence of individual immune status and other cofactors in disease manifestations (Murray et al. 2005).
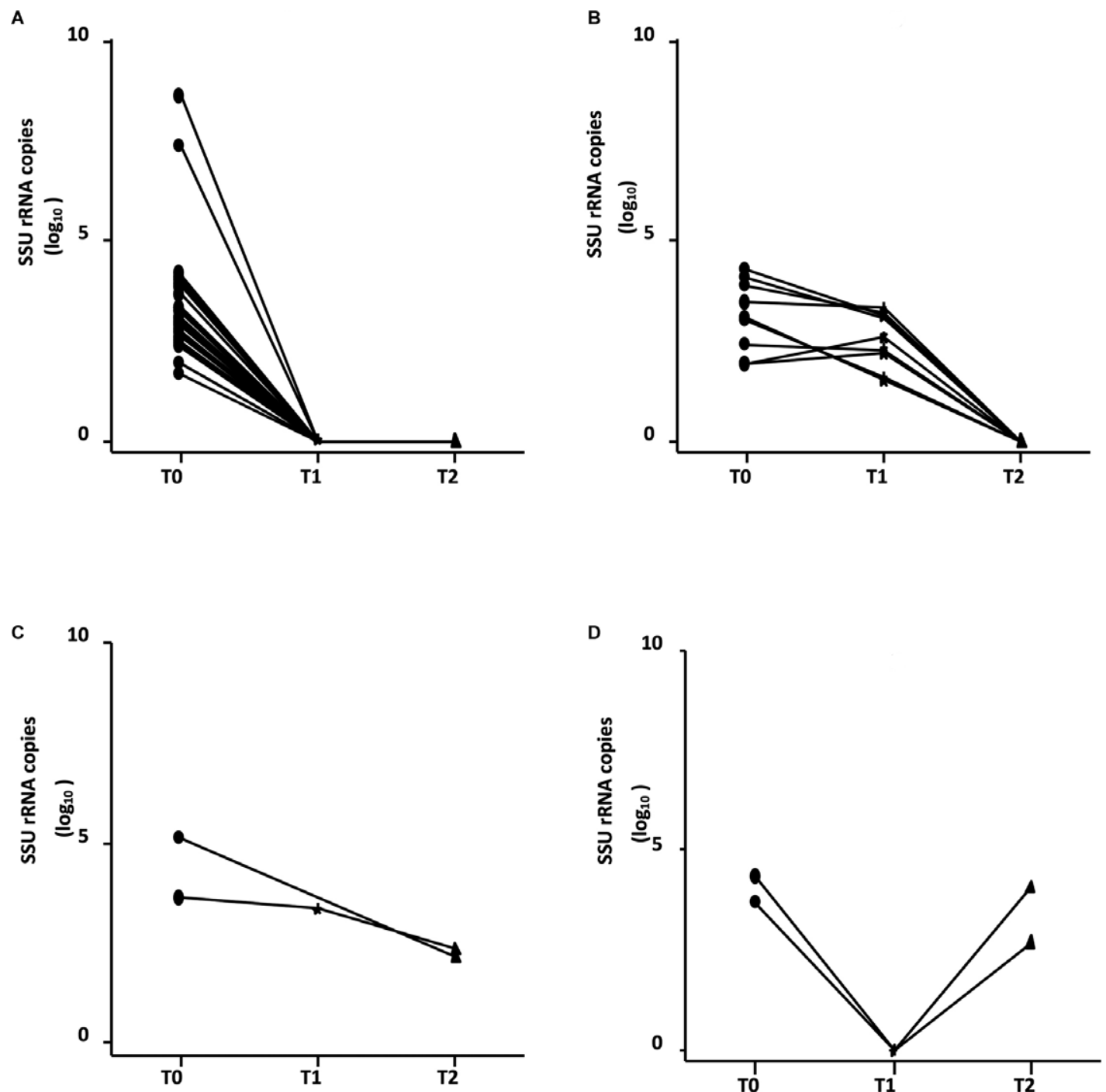

Fig. 2: number of small-subunit ribosomal RNA (SSU rRNA) copies (in $\log _{10}$ ) before starting treatment (T0), between 10-15 days after initiation of treatment (T1) and between 40-60 days after initiation of treatment (T2) in 43 children with visceral leishmaniasis hospitalised at João Paulo II Hospital, June 2010-2011. A: 29 patients with an undetectable parasite DNA at T1 and T2; B: 10 patients with an undetectable parasite DNA only at T2; C: two patients with a decreased but detectable parasite DNA at T2; D: two patients with an undetectable parasite DNA at T1 and a detectable parasite DNA at $\mathrm{T} 2$. 


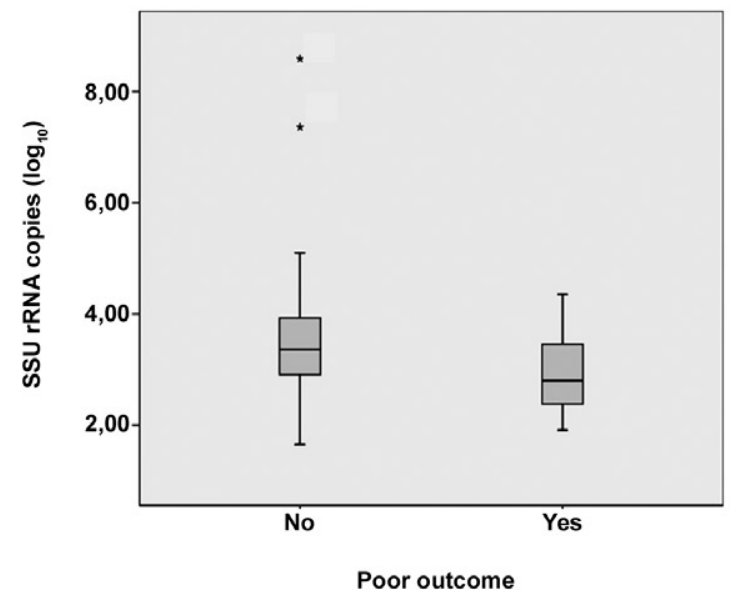

Fig. 3: association between pre-treatment average number of smallsubunit ribosomal RNA (SSU rRNA) copies (in $\log _{10}$ ) and poor outcome among 48 children with visceral leishmaniasis hospitalised at João Paulo II Hospital, June 2010-June 2011.

A higher parasite load might reinforce the specific immune response, which could enhance the host response and the disease resolution. But, considering the small sample size and large variation of parasite load, new data are needed to confirm these findings.

The small number of patients is also a limitation of the present study, once it impaired a more extensive statistical analysis, including multivariate analysis for poor outcome predictors.

In this study, the definition of poor outcome may be a limitation, but it was necessary to redefine the endpoint once there are no deaths during the study period. Clinical outcome is influenced by the access to advanced medical resources, including an ICU, mechanical ventilation and blood transfusions and by medical staff decisions and experience with the disease. The advantages of this study were the prospective design and the uniform assessment performed by a small number of doctors.

In summary, age $\leq 12$ months old, tachydyspnoea, bacterial infection, liver size $\geq 10 \mathrm{~cm}$ and serum albu$\min \leq 2.5 \mathrm{~g} / \mathrm{dL}$ were associated with poor outcome. Patients with these pre-treatment findings should be carefully monitored to offer proper assistance to those with a greater risk of complications. Pre-treatment parasite load in peripheral blood showed a good association with diagnosis and treatment response, but was not associated with poor outcome in paediatric patients.

\section{ACKNOWLEDGEMENTS}

To the staff of the HJPII, for the assistance to the patients included in this study.

\section{REFERENCES}

Abdelmoula MS, M'Hamdi Z, Amri F, Tebib N, Turkia HB, Dridi MFB 2003. Visceral leishmaniasis in children: prognostic factors. Tunis Med 81: 535-539.

Alvar J, Vélez ID, Bern C, Herrero M, Desjeux P, Cano J, Jannin J, den Boer M, Team WLC 2012. Leishmaniasis worldwide and global estimates of its incidence. PLOS ONE 7: e35671.
Antinori S, Calattini S, Piolini R, Longhi E, Bestetti G, Cascio A, Parravicini $\mathrm{C}$, Corbellino $\mathrm{M}$ 2009. Is real-time polymerase chain reaction (PCR) more useful than a conventional PCR for the clinical management of leishmaniasis? Am J Trop Med Hyg 81: 46-51.

Aoun K, Chouihi E, Amri F, Alaya NB, Raies A, Mary C, Bouratbine A 2009. Short report: contribution of quantitative real-time polymerase chain reaction to follow-up of visceral leishmaniasis patients treated with meglumine antimoniate. Am J Trop Med Hyg 81: 1004-1006.

Araújo VE, Morais MH, Reis IA, Rabello A, Carneiro M 2012. Early clinical manifestations associated with death from visceral leishmaniasis. PLoS Negl Trop Dis 6: e1511.

Bossolasco S, Gaiera G, Olchini D, Gulletta M, Martello L, Bestetti A, Bossi L, Germagnoli L, Lazzarin A, Uberti-Foppa C, Cinque P 2003. Real-time PCR assay for clinical management of human immunodeficiency virus-infected patients with visceral leishmaniasis. J Clin Microbiol 41: 5080-5084.

Braga ASC, Toledo Jr ACC, Rabello A 2013. Factors of poor prognosis of visceral leishmaniasis among children under 12 years of age. A retrospective monocentric study in Belo Horizonte, state of Minas Gerais, Brazil, 2001-2005. Rev Soc Bras Med Trop 46: 55-59.

Collin S, Davidson R, Ritmeijer K, Keus K, Melaku Y, Kipngetich S, Davies C 2004. Conflict and kala-azar: determinants of adverse outcomes of kala-azar among patients in southern Sudan. Clin Infect Dis 38: 612-619.

Costa CH, Werneck GL, Costa DL, Holanda TA, Aguiar GB, Carvalho AS, Cavalcanti JC, Santos LS 2010. Is severe visceral leishmaniasis a systemic inflammatory response syndrome? A case control study. Rev Soc Bras Med Trop 43: 386-392.

da Silva MR, Stewart JM, Costa CH 2005. Sensitivity of bone marrow aspirates in the diagnosis of visceral leishmaniasis. Am J Trop Med Hyg 72: 811-814.

Fisa R, Riera C, Ribera E, Gállego M, Portús M 2002. A nested polymerase chain reaction for diagnosis and follow-up of human visceral leishmaniasis patients using blood samples. Trans $R$ Soc Trop Med Hyg 96 (Suppl. 1): S191-S194.

Ghany MG, Nelson DR, Strader DB, Thomas DL, Seeff LB 2011. An update on treatment of genotype 1 chronic hepatitis $C$ virus infection: 2011 practice guideline by the American Association for the study of liver diseases. Hepatology 54: 1433-1444.

Gomes LI, Gonzaga FM, de Morais-Teixeira E, de Souza-Lima BS, Freire VV, Rabello A 2012. Validation of quantitative real-time PCR for the in vitro assessment of antileishmanial drug activity. Exp Parasitol 131: 175-179.

Kubista M, Andrade JM, Bengtsson M, Forootan A, Jonák J, Lind K, Sindelka R, Sjöback R, Sjögreen B, Strömbom L, Stáhlberg A, Zoric N 2006. The real-time polymerase chain reaction. Mol Aspects Med 27: 95-125.

Lyons S, Veeken H, Long J 2003. Visceral leishmaniasis and HIV in Tigray, Ethiopia. Trop Med Int Health 8: 733-739.

Marques LHS, Gomes LI, da Rocha IC, da Silva TA, Oliveira E, Morais MH, Rabello A, Carneiro M 2012. Low parasite load estimated by qPCR in a cohort of children living in urban area endemic for visceral leishmaniasis in Brazil. PLoS Negl Trop Dis 6: e1955.

Mary C, Faraut F, Drogoul MP, Xeridat B, Schleinitz N, Cuisenier B, Dumon H 2006. Reference values for Leishmania infantum parasitemia in different clinical presentations: quantitative polymerase chain reaction for therapeutic monitoring and patient follow-up. Am J Trop Med Hyg 75: 858-863.

Mary C, Faraut F, Lascombe L, Dumon H 2004. Quantification of Leishmania infantum DNA by a real-time PCR assay with high sensitivity. J Clin Microbiol 42: 5249-5255. 
MS - Ministério da Saúde Brasil 2011a. Casos confirmados de leishmaniose visceral. Brasil, grandes regiões e unidades federadas, 1990-2010. Available from: portal.saude.gov.br/portal/arquivos/ pdf/lv_casos_05 09 11.pdf.

MS - Ministério da Saúde Brasil 2011b. Letalidade de leishmaniose visceral. Brasil, grandes regiões e unidades federadas, 2000 2010. Available from: portal.saude.gov.br/portal/arquivos/pdf/ lv letalidade 0509 11.pdf.

Mueller Y, Mbulamberi DB, Odermatt P, Hoffmann A, Loutan L, Chappuis F 2009. Risk factors for in-hospital mortality of visceral leishmaniasis patients in eastern Uganda. Trop Med Int Health 14: $910-917$

Murray HW, Berman JD, Davies CR, Saravia NG 2005. Advances in leishmaniasis. Lancet 366: 1561-1577.

Musso O, Sommer P, Drouet E, Cotte L, Neyra M, Grimaud JA, Chevallier M 1996. In situ detection of human cytomegalovirus DNA in gastrointestinal biopsies from AIDS patients by means of various PCR-derived methods. J Virol Methods 56: 125-137.

Oliveira AL, Paniago AM, Dorval ME, Oshiro ET, Leal CR, Sanches M, Cunha RV, Bóia MN 2006. Emergent outbreak of visceral leishmaniasis in Mato Grosso do Sul state. Rev Soc Bras Med Trop 39: 446-450.

Overbergh L, Valckx D, Waer M, Mathieu C 1999. Quantification of murine cytokine mRNAs using real time quantitative reverse transcriptase PCR. Cytokine 11: 305-312.

Panel on Antiretroviral Guidelines for Adults and Adolescents 2013. Guidelines for the use of antiretroviral agents in HIV-1 infected adults and adolescents. Department of Health and Human Services. Available from: aidsinfo.nih.gov/contentfiles/lvguidelines/ adultandadolescentgl.pdf.
Pedrosa CM, da Rocha EM 2004. Clinical and epidemiological aspects of visceral leishmaniasis in children up to 15 years of age in Alagoas, Brasil. Rev Soc Bras Med Trop 37: 300-304.

PBH/SMS - Prefeitura Belo Horizonte/Secretaria Municipal de Saúde 2012. Vigilância epidemiológica da leishmaniose visceral em BH, Belo Horizonte. Available from: portalpbh.pbh.gov.br/pbh/ecp/ comunidade.do?evento $=$ portlet $\&$ pIdPlc $=$ ecpTaxonomiaMenuPor tal\&app $=$ saude $\& \operatorname{tax}=22301 \&$ lang $=p t \_B R \& p g=5571 \& \operatorname{taxp}=0 \&$.

Rey LC, Martins CV, Ribeiro HB, Lima AA 2005. American visceral leishmaniasis (kala-azar) in hospitalized children from an endemic area. J Pediatr 81: 73-78.

Sampaio MJ, Cavalcanti NV, Alves JG, Filho MJ, Correia JB 2010. Risk factors for death in children with visceral leishmaniasis. PLoS Negl Trop Dis 4: e877.

Santos MA, Marques RC, Farias CA, Vasconcelos DM, Stewart JM, Costa DL, Costa CH 2002. Predictors of an unsatisfactory response to pentavalent antimony in the treatment of American visceral leishmaniasis. Rev Soc Bras Med Trop 35: 629-633.

Seaman J, Mercer AJ, Sondorp HE, Herwaldt BL 1996. Epidemic visceral leishmaniasis in southern Sudan: treatment of severely debilitated patients under wartime conditions and with limited resources. Ann Intern Med 124: 664-672.

Sudarshan M, Weirather JL, Wilson ME, Sundar S 2011. Study of parasite kinetics with antileishmanial drugs using real-time quantitative PCR in Indian visceral leishmaniasis. $J$ Antimicrob Chemother 66: 1751-1755.

Werneck GL, Batista MS, Gomes JR, Costa DL, Costa CH 2003. Prognostic factors for death from visceral leishmaniasis in Teresina, Brazil. Infection 31: 174-177. 